\title{
CORRELATIONS BETWEEN FINANCIAL INDICATORS OF COMPANIES AND SUSTAINABLE DEVELOPMENT INDICATORS
}

\author{
loana Crăciun (Timofei) ${ }^{1}$, Diana Sabău-Popa ${ }^{2}$, Réka Lakatos-Fodor ${ }^{1}$ \\ ${ }^{1}$ Doctoral School of Economic Sciences, Faculty of Economic Sciences, University of \\ Oradea, Romania \\ ${ }^{2}$ Faculty of Economic Sciences, University of Oradea, Romania, \\ ioana.cristina.craciun@gmail.com \\ dianasabaupopa@yahoo.ro \\ lakatos82reka@gmail.com
}

\begin{abstract}
One of the main objectives of sustainable development is to improve living standards and obtain a friendlier business environment, by increasing their competitiveness and performance and the main goal of companies are to achieve a productive activity that ensures their short-term success, but also to pay attention to long-term survival. This analysis was performed to assess the influence of financial indicators of companies and their contribution on the sustainable development of the North-West region of Romania. The research follows the evolution of sustainable development and financial indicators of the sample of 37 companies listed on the BSE, with data collected from 2008-2019, covering the following sectors according to their BSE classification: manufacturing, trade, hotels, construction. In this paper is used both qualitative and quantitative research methods. Among the qualitative research methods used it can be mentioned: observation, comparison and analysis of data. The econometric analysis is based on the estimation of a panel data regression technique and the decision between the random effects model and the fixed effects model was based on the Hausman test. The microeconomic indicators used to analyse the connection with the indicators of sustainable development of the North-West region of Romania are turnover, net profit and the average number of employees used as independent variables and the indicators selected based on information provided by the National Institute of Statistics for the North-West region, called Territorial Sustainable Development Indicators, are the following: Regional Gross Domestic Product, GDP per inhabitant, economically active population, the employment rate of the working age population, the job vacancy rate and the unemployment rate used as dependent variables. The results of the correlation analysis of the parameters showed a weak, insignificant influence between the financial indicators and the sustainable development indicators, the observed data do not allow the identification of a valid linear model.
\end{abstract}

Keywords: indicators; panel data; GDP; turnover; employment

JEL Classification: Q01; R11; E27; C23

\section{Introduction}

In a world in constant motion and transformation, influenced by economic and financial crises, technologies, ideas, businesses, people and even epidemic diseases cross borders with unprecedented speed and intensity, the main goal of companies being to achieve a productive activity that ensure their short-term success, but also pay attention to long-term survival.

The terms sustainable development, sustainability, social responsibility or corporate responsibility are used more and more and are often treated as synonyms. Corporate social responsibility improves the performance of a company's sustainable development through social responsibility activities (Simionescu, 2018). 
The key players in sustainable development are local authorities, the business environment through the contributions of all sectors and companies, civil society, but also other stakeholders in the implementation of sustainable development goals.

One of the main objectives of sustainable development is to improve living standards and obtain a friendlier business environment, both for Romanian enterprises in the region and for foreign companies, by increasing their competitiveness and performance.

This analysis was performed in order to assess the influence of financial indicators of companies and their contribution on the sustainable development of the North-West region of Romania. The main indicators of sustainable development, called Territorial Sustainable Development Indicators, are influenced by a variety of factors, the impact of which can be estimated using appropriate models.

\section{Literature review}

Thi Thu (2020) and his collaborators analysed the relationship between a firm's sustainable development practices and its financial performance, using data from the application of questionnaires to 389 vietnamese textile companies. The research started from three hypotheses, namely: the sustainable development practices of a company will have a positive effect on its financial performance; customer loyalty, employee satisfaction and corporate reputation mediate the positive relationship between sustainable development practices and financial performance; Entrepreneurship has a positive effect on the relationship between sustainable development practices and financial performance. The results show that sustainable development practices positively affect financial performance directly and indirectly through customer loyalty, employee satisfaction and corporate reputation.

Another author who analyses the role and influence of economic development in the region from the perspective of small enterprises is Zvarych (2017). The results of his research established that the functioning of small enterprises significantly influences the sectorial structure of the territory and the level of employment, while the influence on the infrastructure and the ecological status of the region is not significant. The factors that determine the level of efficiency of the operation of small enterprises and also have a significant influence on the level of economic development of the region are: the number of small enterprises; turnover of products sold; the number of employees and the proportion of employees in small enterprises. Based on the research carried out, the author proposes conceptual principles, in order to assess the influence of small businesses on the economic development of the region, which has been the basis for scientific research on the formation of an effective model for sustainable development of the region.

The analysis of the influence of GDP on other microeconomic or macroeconomic variables, but also of them on the GDP has always been a widely debated topic by specialists. For example, Anghelache $(2013 ; 2017)$ has a series of papers on macroeconomic models used in the structural analysis of GDP. In 2013, it analyzes retail turnover and its influence on GDP and concluded that although total turnover has a positive influence on GDP, taken separately from retail turnover in companies owned mainly by state and turnover in retail in mainly private sector companies influence GDP in a negative way, noting that in the model considered, the influence of leisure, as an image of the factors that were not included in the model, it is significant and causes a significant decrease in the value of GDP. In 2017, it tests again the influence of the turnover of the companies with retail activity on GDP, reaching the conclusion that the turnover coming from the companies with private capital influences the GDP in a positive way, and those with full state capital, in a negative sense.

\section{Data and methodology}

The study sample consists of 37 companies from the North-West region, using as a selection criterion their listing on the Bucharest Stock Exchange and the most relevant size criteria reported each year in the financial statements: total assets, net turnover and the average number of employees.

In order to analyse the connection between the variables, we used the information provided by the website of the National Institute of Statistics and the Bucharest Stock Exchange, and at the level of each company, we extracted the financial reports for the period 2008-2019. 
The financial - accounting indicators used to assess the contribution to the sustainable development of the North-West region of Romania are: turnover, net profit and average number of employees, and the indicators selected based on information provided by the National Institute of Statistics for the North-West region, on sustainable development at territorial level are: Gross Domestic Product at regional level, GDP/inhabitant, economically active population, employment rate of the working age population, vacancy rate and unemployment rate.

The econometric analysis is based on the estimation of a panel-type data regression, based on 444 observations; the number of observations represents the number of listed companies that made up the sample (37) multiplied by the years of study (12). The regression model was used to establish the influence that companies' performance indicators have on the Territorial Sustainable Development Indicators of the North-West Region of Romania.

A regression on panel data differs from a simple cross-sectional regression or one that uses time series in that it has a double index on its variables.

$y_{i t}=\alpha_{i}+x_{i t} \times \beta+u_{i t}$, where $i=1, \ldots, 37 ; t=1, \ldots, 12 ; y$ is the dependent, endogenous, explained variable; $x$ is the independent, exogenous, explanatory variable; $\alpha$ is called the free term (intercept), $\beta$ is the regression coefficient, it shows how many units the variable y changes, when the variable $x$ increases by one unit; $u_{i t}$ is a random error, a residual value. The index i shows the cross-sectional dimension and the index $t$ on the temporal one. Most applications use a model with a single error component, of the form: $u_{i t}=\alpha_{i}+\varepsilon_{i t}$.

There are several types of data panel templates. The main distinction is between fixed effects (FE) and random effects (RE) models. In fixed effect models, the $\alpha_{i}$ error component can be correlated with $x_{i t}$ regressors, but the hypothesis that there is no correlation between $x_{i t}$ and the Eit random component is still maintained. In RE models, it is assumed that the error $\alpha_{i}$ is totally random, a stronger hypothesis, which implies its non-correlation with the regressors (Aparaschivei, 2012).

Fixed effects occur when the characteristics are approximately constant between observations and over time (any change that occurs is more or less the same over time). Random effects occur when variables are unpredictable, random (Sabău-Popa, 2020).

Following the estimation of the parameters of the simple regression model, we take into account the following categories of information:

1. Estimated parameters $=$ Coefficient.

2. Significance threshold $-\alpha \varepsilon[0,1]=$ Prob.

3. Determination ratio $-\mathrm{R}^{2}=\mathrm{R}$-squared.

4. Statistics $F$ used to determine the link and the intensity of the link between the variables, at the level of the total population. The Student test (t-statistics) is used to test the parameters of the equation.

5. Corresponding significance threshold $=$ Prob (F-statistic). If the value is greater than 0.05 (0.01), then we reject the null hypothesis. Under these conditions we can say that the explanatory variable is correctly introduced in the regression model (Andrei et all., 2018).

Testing the intensity of the link at the level of the total population is performed based on the test $\mathrm{F}$. Statistical hypotheses: $\mathrm{H}_{0}$ : the correlation ratio does not differ significantly from 0 . The independent variable does not have a significant influence on the dependent variable. Rsquared is not significant in the total population; $\mathrm{H}_{1}$ : the correlation ratio differs significantly from 0 . The independent variable has a significant influence on the dependent variable. $\mathrm{R}$ squared is statistically significant in the total population;

From the point of view of the correlation ratio, if Prob (F-statistic) is below the significance threshold of $5 \%$, we reject hypothesis $\mathrm{H}_{0}$ and admit as true hypothesis $\mathrm{H}_{1}$. The interpretation of the values of $p$ is done as follows: if $p<0.05$, the statistical link is significant, if $p>0.05$, the statistical link is insignificant. 


\section{Empirical results}

Among the sustainable development indicators analysed, we first considered the GDP, for which we followed the evolution after the financial crisis from 2008 to 2019. The use of statistical tests implemented using the Eviews software for the GDP data series, in the NorthWest region, provided the following information:

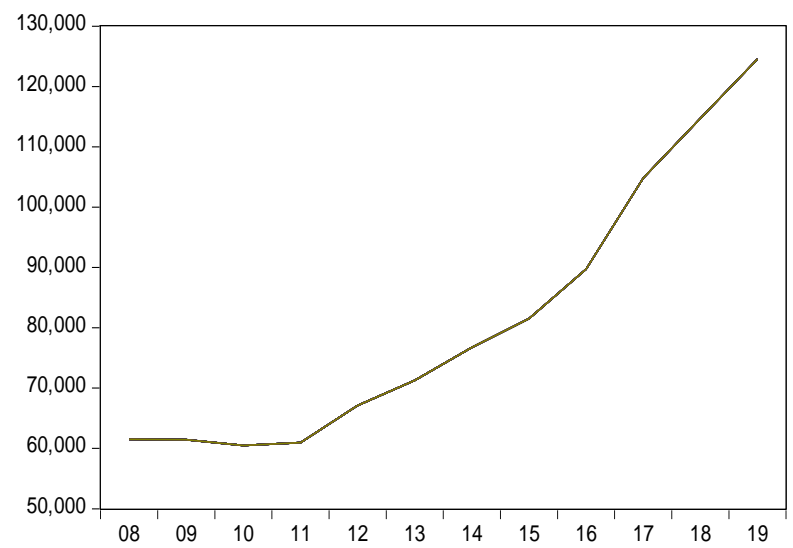

Figure 1: Evolution of GDP in the Northwest in the period 2008-2019 Source: Data processed using the Eviews program

In the period 2008-2019, the GDP at regional level registered an increase of $102.38 \%$, this being achieved in leaps, with positive evolutions, with an average annual growth of $6.74 \%$. We can observe a slight decrease between 2009-2010, the region being affected by the global economic crisis, the decrease being $0.13 \%$ in 2009 and $1.6 \%$ in 2010 . The evolution of GDP in the period 2011-2012, was slightly increasing, in the context in which domestically and internationally the crisis has continued to affect economic growth.
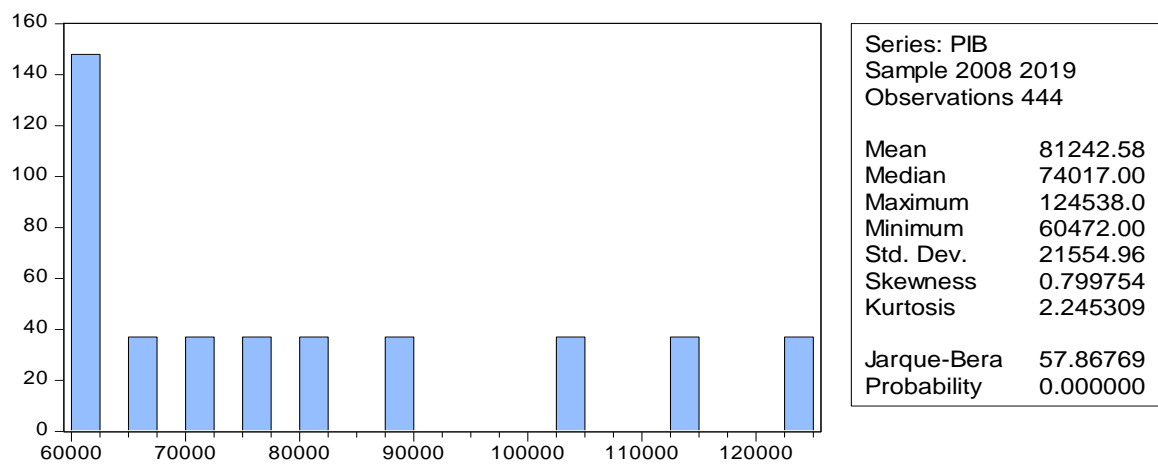

Figure 2: Descriptive statistics on GDP in the Northwest during 2008-2019

Source: Data processed using the Eviews program

The average value of the GDP for the period $2008-2019$ is $81,242.58$ million lei, with a variation between a minimum of 60,472 million lei and a maximum of 124,538 million lei. The distribution of the values of GDP for the considered interval is not a perfectly symmetrical one (the value of the skewness test is non-zero).

In the literature, a fixed effects model or a random effects model is used to estimate a panel data model. The fixed effects model shows the relationship between the exogenous variable and the endogenous variable, in which each individual component has a significant role in 
predicting the outcome in the system. In the case of the random effects model, the variation between entities is assumed to be random and uncorrelated with the exogenous variables included in the model. A first step in the analysis of panel data involves whether or not the differences between the fixed-effect parameter estimator and the random-effect parameter estimator are significant, and the choice of a single method, ie the most appropriate. To determine which model is more suitable for the data series, we used the Hausman test (1978). According to the Hausman test, if the null hypothesis is true, the random effects estimator is effective, and the difference between the estimators must be close to zero. If the null hypothesis is rejected, the fixed effects are tested. (Bădulescu et all., 2018).

According to the results presented in Table 1, the random effects model predominates in most cases, the null hypothesis of the Hausman test is accepted when the probability value> 0.05 .

The first three selected indicators of sustainable development: GDP at regional level, GDP/inhabitant and the economically active population were correlated with the indicators of companies at their absolute value, while for the employment rate of the working age population, the vacancy rate and the unemployment rate were used standardized values of the variables, given that the measurement scales are different and the interpretation of the coefficients can distort the image of the importance of independent variables in the model. The analyzed period was 12 years (2008-2019), except for GDP/inhabitant for which the period was 6 years (2012-2017) according to the existing data on the INSSE website. Going through the steps of generating the regression equation, we arrived at the following results:

Table 1: Panel data analysis - company indicators (exogenous variables) and sustainable development indicators, in absolute values

\begin{tabular}{|c|c|c|c|}
\hline \multirow[b]{2}{*}{ IDDT } & \multicolumn{3}{|c|}{ Endogenous variable } \\
\hline & GDP at regional level & GDP/inhabitant & $\begin{array}{l}\text { The economically } \\
\text { active population }\end{array}$ \\
\hline \multicolumn{4}{|c|}{ The influence of Turnover } \\
\hline $\begin{array}{l}\text { Hausman test } \\
\text { Chi-Sq. Statistic [Prob.] }\end{array}$ & $0.014064[0.9056]$ & $0.316538[0.5737]$ & $0.062419[0.8027]$ \\
\hline Model & Random effects & Random effects & Random effects \\
\hline Intercept [Prob.] & $81296.32[0.0000]$ & $31701.58[0.0000]$ & $1209.596[0.0000]$ \\
\hline Turnover [Prob.] & $-1.28 \mathrm{E}-06[0.9332]$ & $1.10 \mathrm{E}-06[0.8770]$ & 5.05E-09 [0.8598] \\
\hline R-squared & 0.000017 & 0.000130 & 0.000077 \\
\hline F-statistic [Prob.] & $0.007657[0.930311]$ & $0.028638[0.865772]$ & $0.033980[0.853835]$ \\
\hline $\begin{array}{ll}\text { Number } & \text { of } \\
\text { observations }\end{array}$ & 444 & 222 & 444 \\
\hline \multicolumn{4}{|c|}{ The influence of Net Profit } \\
\hline $\begin{array}{l}\text { Hausman test } \\
\text { Chi-Sq. Statistic [Prob.] }\end{array}$ & $0.050468[0.8223]$ & $0.013647[0.9070]$ & $0.153965[0.6948]$ \\
\hline Model & Random effects & Random effects & Random effects \\
\hline Intercept [Prob.] & $81197.39[0.0000]$ & $31732.16[0.0000]$ & $1209.618[0.0000]$ \\
\hline Net Profit [Prob.] & $6.94 \mathrm{E}-05[0.2383]$ & $6.98 \mathrm{E}-06[0.6951]$ & 7.54E-08 [0.0397] \\
\hline R-squared & 0.003422 & 0.000836 & 0.010364 \\
\hline F-statistic [Prob.] & $1.517743[0.218616]$ & $0.184155[0.668246]$ & $4.629067[0.031976]$ \\
\hline $\begin{array}{ll}\begin{array}{l}\text { Number } \\
\text { observations }\end{array} & \text { of } \\
\end{array}$ & 444 & 222 & 444 \\
\hline \multicolumn{4}{|c|}{ The influence of Average number of employees } \\
\hline $\begin{array}{l}\text { Hausman test } \\
\text { Chi-Sq. Statistic [Prob.] }\end{array}$ & $18.988642[0.0000]$ & $6.314183[0.0120]$ & $0.172348[0.6780]$ \\
\hline Model & Fixed effects & Fixed effects & Random effects \\
\hline Intercept [Prob.] & $88457.19[0.0000]$ & $33967.7[0.0000]$ & $1209.810[0.0000]$ \\
\hline
\end{tabular}


The Annals of the University of Oradea. Economic Sciences

TOM XXX, $1^{\text {st }}$ Issue, July 2021

\begin{tabular}{|lc|c|c|c|}
\hline \hline $\begin{array}{l}\text { Average number } \\
\text { employees [Prob.] }\end{array}$ & -32.03957 [0.0000] & -11.05729 [0.0073] & -0.000637 [0.7742] \\
\hline R-squared & 0.064663 & 0.038517 & 0.000203 \\
\hline F-statistic [Prob.] & $0.758594[0.847361]$ & $0.199220[1.000000]$ & $0.089677[0.764729]$ \\
\hline $\begin{array}{l}\text { Number } \\
\text { observations }\end{array}$ & 444 & 222 & 444 \\
\hline
\end{tabular}

Source: Data processed using the Eviews program

In order to interpret how the indicators of companies influence the regional GDP (dependent variable), we follow the probability of the coefficients of independent variables. The results show that the dependent variable is positively associated only with the net profit, but of the three indicators analyzed, only the probability of the coefficient of the average number of employees is below the 5\% threshold, which means that at a $1 \%$ increase in the number of employees, the product GDP decreases by $32.03 \%$. However, given the F test and Prob (Fstatistic) which is above the $5 \%$ significance threshold, it can be said that the three models that have the regional GDP as a dependent variable are not significantly related and cannot be used for the analysis of the dependence between the analyzed variables, and R-Squared is very small.

As in the case of the regional GDP, for the dependent variable GDP/inhabitant, the probability of the coefficient of the average number of employees is below the threshold of $5 \%$, and because the regression model has free term and the value of R-square is 0.038517 , we can say that $3.85 \%$ of the dispersion of the data series of the GDP/inhabitant variable is explained by the variable average number of employees, so that at a $1 \%$ increase in the number of employees, the GDP/inhabitant decreases by $11,05 \%$. But the influence of company indicators is insignificant given that the result of Prob (F-statistic) is above the significance threshold of $5 \%$ (the value 1 in the case of the average number of employees indicates that there is no link between variables) and $\mathrm{R}$-Squared has a very small value.

For the indicator The economically active population (dependent variable), Prob (F-statistic) is above the significance threshold of $5 \%$ in the case of turnover and average number of employees, so it can be said that the intensity of the connection is very weak and R-Squared is very small. Even if in the case of net profit, Prob (F-statistic) is below the significance threshold of $5 \%(0.031976)$, R-Squared is very small: only $1.04 \%$ of the variation of the dependent variable is explained by the model. Analyzing the coefficient of the independent variable, we can say that it is positively associated, which indicates that an increase in net profit by $1 \%$, the active population increases, in this case by a very small percentage, by $0.00000754 \%$.

Table 2: Analysis of panel data - company indicators (exogenous variables) and sustainable development indicators (dependent variables), in relative, standardized values

\begin{tabular}{|c|c|c|c|}
\hline \multirow[b]{2}{*}{ IDDT } & \multicolumn{3}{|c|}{ Endogenous variable } \\
\hline & $\begin{array}{l}\text { The employment } \\
\text { rate of the working } \\
\text { age population }\end{array}$ & The vacancy rate & $\begin{array}{c}\text { The unemployment } \\
\text { rate }\end{array}$ \\
\hline \multicolumn{4}{|c|}{ The influence of Turnover } \\
\hline $\begin{array}{l}\text { Hausman test } \\
\text { Chi-Sq. Statistic [Prob.] }\end{array}$ & $0.021363[0.8838]$ & $0.266096[0.6060]$ & $0.090200[0.7639]$ \\
\hline Model & Random effects & Random effects & Random effects \\
\hline Intercept [Prob.] & $3.48 \mathrm{E}-14[1.0000]$ & $-1.22 \mathrm{E}-13[1.0000]$ & $-1.67 E-10[1.0000]$ \\
\hline Turnover [Prob.] & $-0.005130[0.9177]$ & $0.018096[0.7154]$ & $-0.010539[0.8319]$ \\
\hline R-squared & 0.000026 & 0.000327 & 0.000111 \\
\hline F-statistic [Prob.] & $0.011631[0.914167]$ & 0.144784 [0.703753] & $0.049100[0.824740]$ \\
\hline Number of observations & 444 & 444 & 444 \\
\hline \multicolumn{4}{|c|}{ The influence of Net Profit } \\
\hline
\end{tabular}


The Annals of the University of Oradea. Economic Sciences

TOM XXX, $1^{\text {st }}$ Issue, July 2021

\begin{tabular}{|c|c|c|c|}
\hline $\begin{array}{l}\text { Hausman test } \\
\text { Chi-Sq. Statistic [Prob.] }\end{array}$ & $0.125587[0.7231]$ & $0.185175[0.6670]$ & $0.156304[0.6926]$ \\
\hline Model & Random effects & Random effects & Random effects \\
\hline Intercept [Prob.] & $-2.07 E-13[1.0000]$ & $-2.51 \mathrm{E}-13[1.0000]$ & $-1.66 \mathrm{E}-10[1.0000]$ \\
\hline Net Profit [Prob.] & $0.092037[0.0632]$ & $0.111527[\mathbf{0 . 0 2 4 2}]$ & $-0.102568[\mathbf{0 . 0 3 8 3}]$ \\
\hline R-squared & 0.008471 & 0.012438 & 0.010520 \\
\hline F-statistic [Prob.] & $3.776122[0.052624]$ & $5.566974[0.018736]$ & $4.699354[0.030707]$ \\
\hline Number of observations & 444 & 444 & 444 \\
\hline \multicolumn{4}{|c|}{ The influence of Average number of employees } \\
\hline $\begin{array}{l}\text { Hausman test } \\
\text { Chi-Sq. Statistic [Prob.] }\end{array}$ & $18.388086[0.0000]$ & $5.020292[0.0251]$ & $10.065775[0.0015]$ \\
\hline Model & Fixed effects & Fixed effects & Fixed effects \\
\hline Intercept [Prob.] & $8.93 \mathrm{E}-12[1.0000]$ & 4.77E-12 [1.0000] & $-1.73 \mathrm{E}-10[1.0000]$ \\
\hline $\begin{array}{ll}\text { Average number } & \text { of } \\
\text { employees } & \text { [Prob.] }\end{array}$ & $-0.440424[0.0000]$ & $-0.235562[0.0067]$ & $0.330584[0.0001]$ \\
\hline R-squared & 0.062746 & 0.017950 & 0.035351 \\
\hline F-statistic [Prob.] & $0.734602[0.874300]$ & $0.200560[1.000000]$ & $0.402127[0.999411]$ \\
\hline Number of observations & 444 & 444 & 444 \\
\hline
\end{tabular}

Regarding the Employment rate of the working age population, we find that turnover is not significantly correlated with the dependent variable. Even if in the case of net profit, Prob (Fstatistic) is below the significance threshold of $10 \%(0.052624)$, R-Squared is very small: only $0.8 \%$ of the variation of the dependent variable is explained by the model. Since the probability $=0.00$, in relation to the average number of employees and the employment rate of the working age population, the null hypothesis is rejected and it is accepted that the regression model is significant in the total population, but Prob (F-statistic) is above the threshold of significance of $5 \%$, and R-Squared has a very small value.

In the case of the Job Vacancy Rate, the above results highlight the following: companies' indicators are not significantly correlated in terms of turnover and average number of employees, although the probability of the variable coefficient of the average number of employees is below the significance threshold of 5\%, but Prob for F-statistic is above the 5\% threshold, the value 1 in this case indicates that there is no connection between the variables. In the case of the independent variable net profit, the model is correctly specified, because the $p$-value for $\mathrm{F}$-statistic is 0.018736 , below the $5 \%$ threshold, and the probability of the variable coefficient is 0.0242 . Thus we can say that the vacancy rate is positively associated with net profit, which indicates that the change with a standard deviation of the value of net profit variable, produces a change by $0.11 \%$ standard deviation of the value of the dependent variable the vacancy rate..

Regarding The unemployment rate, there is a very weak link intensity because the probability of F-statistic in the case of turnover has a value higher than 0.05 . The same information is obtained at the probability of F-statistic corresponding to the variable of the average number of employees, but the probability corresponding to the coefficient of the variable of the average number of employees is below the threshold of $5 \%$, but the value of $\mathrm{R}$-square is very small, that only $3.54 \%$ of the dispersion of the data series of the dependent variable is explained by the variable of the average number of employees. But in the case of the independent variable, the net profit, the model is correctly specified, because the $p$ value for F-statistic is 0.030707 , below the $5 \%$ threshold and the probability of the variable coefficient is 0.0383 , however with a very small R-square of only $1.05 \%$. The net profit coefficient shows an insignificant inverse linear link, which assumes that the change with a standard deviation of the value of the variable of net profit, produces a change by $0.1 \%$ standard deviation of the value of variable depending on the unemployment rate. 


\section{Conclusions}

The present research analyzed the relationship between the main macroeconomic indicators of territorial sustainable development in the North-West region of Romania and the performance indicators of companies and their contribution to the sustainable development of the area, using the financial data for the period 2008-2019, in the case of 37 companies in the North-West Region of Romania, listed on the Bucharest Stock Exchange. A panel model was used, the decision between the random effects model and the fixed effects model was based on the Hausman test.

Given that in most of the analyzed models, at the level of the total population, the parameters of the regression equation are not verified, respectively the correlation ratio and not all coefficients are significant, it can be stated that there is no relationship between explanatory and dependent variables, the resulting models being characterized by insignificant values of the R-square tests, and the value close to 0 denotes a very weak bond intensity. At the moment, no predictions have been made. Only a relationship between these indicators was sought. The analysis suggests the vulnerability of companies in northwestern Romania.

The limits of research, which consist in modeling a small number of variables, the existence of other factors that could influence the results, open new research directions that can be extended to cover longer periods, other econometric techniques and financial indicators of companies, to be able to appreciated the contribution of companies to the sustainable development of the area.

\section{References}

1. Andrei, T., Oancea, B., Mirică, A., 2018. Econometrie: teorie și aplicații în Eviews și R; Editura Economică, București.

2. Anghelache, C. și Anghelache, G.V., 2013. Macroeconomic Models Used In The Structural Analysis Of The Gross Domestic Product, Revista Română de Statistică nr. 6 / 2013.

3. Anghelache, C., Manole, A., Anghel, M.,G., 2017. Macroeconomic models used in structural analysis of GDP, Theoretical and Applied Economics, Volume XXIV (2017), No. 1(610), Spring, pp. 197-206.

4. Aparaschivei, L., 2012. Rata ocupării în România. Analiză de tip panel, Economie teoretică şi aplicată, Volumul XIX, No. 7(572), p. 11-22.

5. Bădulescu, D., Simuț, R. și Morutan, R.A., 2018. Foreign Banks in CEE Economies: A Complex Relationship in Uncertain Times, The 12th International Days of Statistics and Economics, Prague.

6. Bucharest Stock Exchange http://www.bvb.ro/

7. National Commission for Strategy and Prognosis http://www.cnp.ro/

8. National Institute of Statistics http://www.insse.ro/cms/

9. Sabău-Popa, C., D., 2020. Computational Intelligence in Financial Management. Applications on the financial indicators of SMEs in Romania and Hungary. București, Ed. Universitară, $10.5682 / 9786062811488$.

10. Simionescu, L. N., 2018. Responsabilitatea socială și performanța financiară a companiilor, Editura ASE, București.

11. Thi Thu, H.P., Tran, H.X., Trung, T.L., Nguyen, N., Pervan, S. And Tran, M.D., 2020. The Relationship between Sustainable Development Practices and Financial Performance: A Case Study of Textile Firms in Vietnam. Sustainability, 12(15), pp. 5930.

12. Zvarych, O., 2017. Evaluation Of Small Business Influence On The Economic Development Of The Region. Baltic Journal of Economic Studies. 3. 151-156. 10.30525/2256-0742/2017-3-5-151-156. 